\title{
Winter and spring variation in daily milk yield and mineral composition of Jersey, Friesian cows and their crosses under a pasture-based dairy system
}

\author{
C.T.W. Nantapo \& V. Muchenje ${ }^{\#}$ \\ Department of Livestock and Pasture Science, Faculty of Science and Agriculture, \\ University of Fort Hare, P Bag X 1314, Alice, 5700, South Africa
}

(Received 28 September 2012; Accepted 28 March 2013; First published online 2 June 2013)

Copyright resides with the authors in terms of the Creative Commons Attribution 2.5 South African Licence. See: http://creativecommons.org/licenses/by/2.5/za/

Condition of use: The user may copy, distribute, transmit and adapt the work, but must recognise the authors and the South African Journal of Animal Science

\begin{abstract}
This study was conducted to determine the effects of genotype and season on daily milk yield (DMY) and mineral composition of pasture-based dairy cows. This was done by collecting data from 20 Friesian, 20 Jersey and 20 Friesian $\times$ Jersey crossbred cows in the early stage of their $4^{\text {th }}$ parity in winter and spring, respectively. Automated milk meters were used to measure the DMY. Mineral composition was determined by using the Inductively Coupled Plasma Optical Emission Spectrometric (ICP-OES) method. The data collected from milk yield and mineral composition were analysed using the general linear model of SAS. The results showed that milk yield was highest from Friesian cows both in spring and winter seasons while Jersey cows had the lowest yield. Seasonal effects were also observed in mineral concentrations, with winter having higher values for aluminium, boron, copper, iron, magnesium, manganese, zinc and sodium while phosphorus was higher in spring. Crossbred cows yielded higher concentrations of calcium, phosphorus and magnesium. It was therefore concluded that both milk yield and mineral compositions are affected by genotype and season.
\end{abstract}

Keywords: Genotype, seasonal effects, mineral content, novel health milk products

\# Corresponding author: vmuchenje@ufh.ac.za

\section{Introduction}

The composition of milk makes it highly nutritious (Huth et al., 2006) and essential for the proper development of the human body (Duhamel \& Sale, 2008). Recent studies in dairy science are based on the consumer preferences as consumers and health professionals have become aware that specific minerals affect human health while some prevent diseases such as tissue cancer at certain concentrations (O'DonnellMegaro et al., 2011). This has led to continued market pressure in the last few years in finding avenues to improve the concentration of beneficial minerals in milk in the most economical ways (Jenkins \& McGuire, 2006). If observed, differences in milk between breeds can be used in strategies to promote milk from cows with a more favourable mineral profile for human health (Eijndhoven et al., 2011) and assigning such breed to a special brand product or high niche product (Dooley et al., 2006). An insight into breed differences in essential and non-essential minerals abundant in milk and important in maintaining healthy body physiological processes will help farmers aiming at producing a value added product (Croissant et al., 2007; Van Hulzen et al., 2009).

There is paucity of information comparing seasonal mineral profiles in both pasture and milk in pasture-based systems. Machado et al. (2005) and Meeske et al. (2006) found changes in total mineral content of ryegrass/clover pastures during winter and spring. Cruywagen et al. (2011) measured digestibility of different pastures and found digestibility differences between breeds. Botha et al. (2008) compared milk yield, fat and protein content from pasture-based cows but, as in all mentioned studies, did not relate this to milk mineral profiles. A seasonal drop in concentrations of zinc and iron with milk yield of Iberian Red Deer 
was observed by Gallego et al. (2006). Such seasonal differences can be used in promoting health improving dairy products. As such, Schonfeldt et al. (2012) highlighted the need for country-specific data on milk mineral composition to improve the overall product. The objective of the present study was to determine the effect of genotype and season on mineral composition of pasture-based Friesian and Jersey and FriesianJersey crossbred cows.

\section{Materials and Methods}

The study was conducted at the University of Fort Hare Dairy Trust farm located in Alice which is 120 $\mathrm{km}$ from East London along the eastern coastline. The geographical location of the farm is $32.8^{\circ} \mathrm{S}$ and $26.9^{\circ}$ $\mathrm{E}$ and lies $520 \mathrm{~m}$ above sea level. The vegetation around the farm is False Thornveld. The weather is divided into spring (hot-dry) (August-October), summer (hot-wet) (November-January), winter (cool-dry) (MayJuly) and autumn (post-rainy) (February-April) seasons. An average of $480 \mathrm{~mm}$ of annual rainfall is mostly received in the summer season while the temperature averages $19.2{ }^{\circ} \mathrm{C}$. The area is generally flat and the soils are mostly shale and mudstone derived. Approximately 200 ha of the farm is divided into 36 paddocks, covered by high yielding perennial rye grass, Lolium multiflorum intersown with clover cultivar, Trifolium repens at a ratio of $4: 1$.

Data were collected from Jersey $(n=20)$, Holstein Friesian $(n=20)$ and Jersey $\times$ Holstein Friesian $(n$ $=20$ ) winter calving, randomly selected and clinically healthy dairy cows from a herd of 850 cows. All study cows used in the present study were in the $4^{\text {th }}$ parity. The cows were managed as one herd and water and pasture were provided ad libitum. Cows were supplemented with a grain-based concentrate during milking based on previous day yield. Silage was also fed during the evening in troughs. Milk sampling was done in winter (cool-dry) and spring (hot-dry). A representative sample was drawn from in-line milk meters from each cow into sterile $100 \mathrm{~mL}$ vacucontainers. No milk-letting agent was administered. Milk samples were immediately stored on ice in the field before transferring them to laboratory in less than 30 minutes. The milk samples were then stored at $-20{ }^{\circ} \mathrm{C}$ pending further analysis. Aseptic techniques were employed when collecting samples to minimise contamination. Average yield was compiled using the electronic package, Afifarm V 3.05ET3 R (2007 Test version- Limited Edition), a component of the 60-stall rotary milking system (Waikato Milking systems, New Zealand) from morning and afternoon milking.

For the determination of all minerals, $0.5 \mathrm{~g}$ of freeze-dried milk samples was digested with concentrated nitric acid $\left(\mathrm{HNO}_{3}\right)$ and perchloric acid $\left(\mathrm{HClO}_{4}\right)$ at $200{ }^{\circ} \mathrm{C}$ using a Varian 207 Liberty 200 machine. Concentrated nitric acid was added to a freeze-dried milk sample and heated (in an open glass digestion tube in a heating block) to $120^{\circ} \mathrm{C}$ (block temperature). After addition of $30 \%$ hydrogen peroxide $\left(\mathrm{H}_{2} \mathrm{O}_{2}\right)$ and distilled water to the nitric acid, the samples were digested for 20 minutes before cooling. All samples were digested in duplicate. An aliquot of the digest solution was used for the Inductively Coupled Plasma Optical Emission Spectrometric (ICP-OES) determination of these minerals. The instrument was set up and operated according to the recommended procedures (Chao-Yong \& Schulte, 1985). Initially, one of the samples was analysed to determine the approximate level of all the elements, and this information was used to prepare a series of standard solutions to calibrate the instrument for accurate analysis of all the samples. These standards contained all the elements of interest in similar proportions to the samples. All sample solutions (duplicate nitric acid only and duplicate perchloric + nitric acid digests) were analysed for each element, and after rejection of possible outliers, the mean of the remaining values was calculated for each element per given sample.

Mineral concentrations and daily milk yield were analysed using the General Linear Model procedure of Statistical Analysis System (SAS) 2003 were the following model was used:

$$
\mathrm{Y}_{\mathrm{ijk}}=\mu+\mathrm{B}_{\mathrm{i}}+\mathrm{T}_{\mathrm{j}}+(\mathrm{B} \times \mathrm{T})_{\mathrm{ij}}+\mathrm{e}_{\mathrm{ijk}}
$$

where $Y_{i j k}$ represents response (milk yield and mineral concentration); $\mu$ is the mean; $B_{i}$ is the effect of genotype; $T_{j}$ is effect of season (winter, spring); $(B \times T)_{i j}$ is interaction between genotype and season and $e_{i j k}$ is the residual error term. Least square means were compared using the PDIFF procedure of SAS.

\section{Results and Discussion}

Milk yield data for Jersey, Friesian and Jersey $\times$ Friesian cows in winter and spring seasons are shown in Table 1. Friesian cows produced the highest $(P<0.001)$ milk yield in all seasons followed by $\mathrm{J} \times \mathrm{F}$ crosses. 
Jersey cows were the lowest $(P<0.001)$ producers. These results are comparable with $30.5 \mathrm{~kg} /$ day observed by Kgole et al. (2012) in South African Holstein cattle and a 305 days average of $16.28 \mathrm{~kg} /$ day in Jersey cows by Meeske et al. (2006). Mostert et al. (2003) and Palladino et al. (2010) reported a similar trend in production with higher milk yield in Holstein-Friesian cows than in Jersey cows. In the current study, more $(P<0.001)$ milk was produced during the spring (hot-dry) than winter season in all breeds. Dodzi \& Muchenje (2012) observed an increased the lying activity in cattle which promotes rumination and increase milk production.

Table 1 Milk yield between Jersey, Friesian and Friesian $\times$ Jersey cross in winter and spring (mean \pm SE)

\begin{tabular}{lccc}
\hline \multirow{2}{*}{ Breed } & \multicolumn{2}{c}{ Milk Yield (litres/day) } & P-value \\
\cline { 2 - 4 } & Winter & Spring & $* * *$ \\
Jersey & $19.3^{\mathrm{e}} \pm 0.38$ & $22.2^{\mathrm{d}} \pm 0.35$ & $* * *$ \\
Friesian $)$ & $27.8^{\mathrm{b}} \pm 0.38$ & $31.9^{\mathrm{a}} \pm 0.37$ & $* * *$ \\
$\mathrm{~J} \times$ F cross & $24.5^{\mathrm{c}} \pm 0.35$ & $27.1^{\mathrm{b}} \pm 0.34$ & \\
& & \\
abcde Row and column means with different superscripts differ significantly $(P<0.001)$. \\
$\mathrm{J} \times$ F cross = Jersey $\times$ Friesian cross.
\end{tabular}

The present study showed significant differences in concentration of most minerals except calcium and potassium, as shown in Table 2. Milk in spring had lower concentrations of zinc $(P<0.05)$, copper $(P$ $<0.01)$, sodium, magnesium, aluminium, boron, iron and manganese but more $(P<0.001)$ abundant phosphorus than milk in winter. The difference in milk mineral concentrations between winter to spring season is due to a "dilution effect" as reported by Guler (2007), which is related to animal feeding behaviour and changes in pasture composition with more succulent, less fibrous (thus ash) material being available for the animal in spring than winter months. This suggests that the animal lags in milk mineral output, which cannot be compensated for by the provided concentrate even with the highest milk yield (Meeske et al., 2006).

Table 2 Seasonal effects on milk mineral concentrations in winter and spring (mean \pm SE)

\begin{tabular}{lccc}
\hline \multirow{2}{*}{ Mineral (mg/L) } & \multicolumn{2}{c}{ Season } & \multirow{2}{*}{$P$-value } \\
\cline { 2 - 4 } Calcium & $1136 \pm 18.5$ & $1153 \pm 17.6$ & Ns \\
Potassium & $1467 \pm 18.3$ & $1501 \pm 17.4$ & Ns \\
Phosphorus & $903^{\mathrm{b}} \pm 16.1$ & $986^{\mathrm{a}} \pm 15.3$ & $* *$ \\
Sodium & $307^{\mathrm{a}} \pm 6.5$ & $251^{\mathrm{b}} \pm 6.2$ & $* * *$ \\
Magnesium & $95^{\mathrm{a}} \pm 1.5$ & $86^{\mathrm{b}} \pm 1.4$ & $* * *$ \\
Aluminium & $1.14^{\mathrm{a}} \pm 0.036$ & $0.43^{\mathrm{b}} \pm 0.034$ & $* * *$ \\
Boron & $0.20^{\mathrm{a}} \pm 0.004$ & $0.15^{\mathrm{b}} \pm 0.004$ & $* * *$ \\
Copper & $0.20^{\mathrm{a}} \pm 0.008$ & $0.17^{\mathrm{b}} \pm 0.008$ & $* *$ \\
Iron & $1.56^{\mathrm{a}} \pm 0.059$ & $0.78^{\mathrm{b}} \pm 0.056$ & $* * *$ \\
Manganese & $0.07^{\mathrm{a}} \pm 0.002$ & $0.04^{\mathrm{b}} \pm 0.002$ & $*$ \\
Zinc & $4.56^{\mathrm{a}} \pm 0.105$ & $4.25^{\mathrm{b}} \pm 0.100$ & \\
& &
\end{tabular}


There was a significant effect of genotype on calcium, phosphorus and magnesium concentration in milk (Table 3). The present study revealed that Friesian $\times$ Jersey crosses produced milk with the highest $(P$ $<0.001)$ calcium, magnesium, aluminium and phosphorus concentrations. Gallego et al. (2006) highlighted the positive relationship between magnesium, calcium and phosphorus. These minerals are linked to milk casein, protein and in their physiological functions. Due to effect of heterosis, Friesian $\times$ Holstein cows produce more protein in milk (Palladino et al., 2010), therefore an improved concentration of calcium, magnesium and phosphorus follows. Besides improving milk yield farmers can use crossbreeding to improve the quality of milk.

Table 3 Genotypic effects on milk mineral concentration of Friesian, Jersey and F $\times$ J cross cows (mean \pm SE)

\begin{tabular}{|c|c|c|c|c|}
\hline \multirow{2}{*}{ Mineral (mg/L) } & \multicolumn{3}{|c|}{ Genotype } & \multirow{2}{*}{$P$-value } \\
\hline & $\mathrm{J} \times \mathrm{F}$ cross & Friesian & Jersey & \\
\hline Calcium & $1175^{\mathrm{a}} \pm 21.0$ & $1109^{b} \pm 22.9$ & $1149^{\mathrm{ab}} \pm 22.3$ & $*$ \\
\hline Potassium & $1494 \pm 20.8$ & $1159 \pm 22.7$ & $1499 \pm 22.1$ & Ns \\
\hline Phosphorus & $986^{\mathrm{a}} \pm 18.3$ & $918^{b} \pm 20.0$ & $929^{b} \pm 19.5$ & * \\
\hline Sodium & $280 \pm 7.3$ & $270 \pm 8.0$ & $287 \pm 7.8$ & Ns \\
\hline Magnesium & $94^{\mathrm{a}} \pm 1.7$ & $87^{b} \pm 1.8$ & $90^{\mathrm{ab}} \pm 1.8$ & $*$ \\
\hline Aluminium & $0.74^{b} \pm 0.041$ & $0.78^{\mathrm{ab}} \pm 0.044$ & $0.82^{\mathrm{a}} \pm 0.043$ & $*$ \\
\hline Boron & $0.17 \pm 0.004$ & $0.17 \pm 0.005$ & $0.17 \pm 0.005$ & Ns \\
\hline Copper & $0.18 \pm 0.010$ & $0.17 \pm 0.010$ & $0.20 \pm 0.010$ & Ns \\
\hline Iron & $1.12 \pm 0.067$ & $1.24 \pm 0.073$ & $1.16 \pm 0.071$ & Ns \\
\hline Manganese & $0.05 \pm 0.003$ & $0.05 \pm 0.003$ & $0.05 \pm 0.003$ & Ns \\
\hline Zinc & $4.39 \pm 0.119$ & $4.55 \pm 0.130$ & $4.27 \pm 0.126$ & Ns \\
\hline
\end{tabular}

${ }^{\text {ab }}$ Row means with different superscripts differ significantly $(P<0.05)$.

Ns: not significant; J x F: Jersey x Friesian.

\section{Conclusion}

The results of the present study indicate that seasonal milk mineral content in Friesian, Jersey and the Friesian $\times$ Jersey cross under a pasture based dairy system differ. There was an increase in milk yield in the spring season but a reduction in the concentrations of most minerals. Novel health milk product development can be based on the milk mineral composition data.

\section{Acknowledgements}

The authors thank Fort Hare Dairy Trust Farm staff, colleagues in the Department of Livestock and Pasture Science, University of Fort Hare for their unwavering support. Special thanks to the Department of Agriculture, Elsenburg Laboratory for mineral analysis and the Govan Mbeki Research and Development Centre for financial support.

\section{References}

Botha, P.R., Meeske, R. \& Snyman, R., 2008. Kikuyu over-sown with ryegrass; Grazing capacity, milk production and milk composition. Afr. J. Range For. Sci. 25 (3), 103-110.

Chao-Yang, L.H. \& Schulte, E.E., 1985. Digestion of plant tissue for analysis by ICP emission spectroscopy. Comm Soil. Sci. Plant Ana. 16, 943-958.

Croissant, A.E., Washburn, S.P., Dean, L.L. \& Drake, M.A., 2007. Chemical properties and consumer perceptions of fluid milk from conventional and pasture-based production systems. J. Dairy Sci. 90, 4942-4953. 
Cruywagen, C.W., Muller, C.J.C. \& Du Toit, F.J., 2011. Ruminal protein and fibre degradability of lucerne hay as affected by regrowth period and dairy breed. S. Afr. J. Anim. Sci. 41, 389-397.

Dodzi, M.S. \& Muchenje, V., 2012. Seasonal variation in time budgets and milk yield for Jersey, Friesland and crossbred cows raised in a pasture-based system. Trop. Anim. Health Prod. 44, 1395-1401.

Dooley, A.E., Parker, W.F., Blair, H.T. \& Lopez-Villalobos, D.E., 2006. Selection and segregation of herds for a valuable milk trait. Livest. Sci. 102, 60-71.

Duhamel, J.F. \& Salle, B., 2008. Newborn and infant nutrition in France, Acad. Nat. Med. Paris. 192, 723-729.

Eijndhoven, M.H.T., Hiemstra, S.J. \& Calus, M.P.L., 2011. Short communication: Milk fat composition of 4 cattle breeds in Netherlands. J. Dairy Sci. 94, 1021-1025.

Gallego, L., Landete-Castillejos, T., Garcia, A. \& Sanchez, P.J., 2006. Seasonal and lactational changes in mineral composition of milk from Iberian Red Deer (Cervus elaphus hispanicus). J. Dairy Sci. 89, 589-595.

Guler, Z., 2007. Levels of 24 minerals in local goat milk, its strained yoghurt and salted yoghurt (tuzlu yogurt). Small Rumin. Res. 71, 130-137.

Huth, P.J., DiRienzo, D.B. \& Miller, G.D., 2006. Major scientific advances with dairy foods in nutrition and health. J. Dairy Sci. 89, 1207-1221.

Jenkins, T.C. \& McGuire, M.A., 2006. Major advances in Nutrition: Impact on Milk composition. J. Dairy Sci. 89, 1302-1310.

Kgole, M.L., Visser, C. \& Banga, C.B., 2012. Environmental factors influencing milk urea nitrogen in South African Holstein cattle. S. Afr. J. Anim. Sci. 42 (5, Suppl. 1), 459-463.

Machado, C.F., Morris, T.S., Hodgson, J. \& Fathalla, M., 2005. Seasonal changes of herbage quality within a New Zealand beef cattle finishing pasture. N. Z. J. Agric. Res. 48 (2), 265-270.

Meeske, R., Rothauge, A., Van der Merwe, G.D. \& Greyling, J.F., 2006. The effect of concentrate supplementation on the productivity of grazing Jersey cows on a pasture based system. S. Afr. J. Anim. Sci. 36, 105-110.

Mostert, B.E., Theron, H.E. \& Kanfer, F.H.J., 2003. Derivation of standard lactation curves for South Afican dairy cows. S. Afr. J. Anim. Sci. 33, 70-77.

O’Donnell-Megaro, A.M., Barbano, D.M. \& Bauman, D.E., 2011. Survey of the fatty acid composition of retail milk in the United States including regional and seasonal variations. J. Dairy Sci. 94, 59-65.

Palladino, R.A., Buckley, F., Prendiville, R., Murphy, J.J., Callan, J. \& Kenny, D.A., 2010. A comparison between Holstein-Friesian and Jersey dairy cows and their $\mathrm{F}_{1}$ hybrid on milk fatty acid comparison under grazing conditions. J. Dairy Sci. 93, 2176-2184.

SAS, 2003. Statistical Analysis System Institute Inc. Users Guide, Version 9, Carry, N.C., USA.

Schonfeldt, H.C., Hall, N.G. \& Smit, L.E., 2012, The need for country specific composition data on milk. Food Res. Int. 47, 207-209.

Van Hulzen, K.J.E., Spong, R.C., Van der Meer, R. \& Van Arendonk, J.A.M., 2009. Genetic and nongenetic variation in concentration of selenium, calcium, potassium, zinc, magnesium and phosphorus in milk of Dutch Holstein-Friesian cows. J. Dairy Sci. 92, 5754-5759. 